\title{
ESTIMASI POTENSI KERUGIAN EKONOMI PADA BALITA OBESITAS YANG DIPREDIKSI MENGALAMI OBESITAS SAAT DEWASA DI INDONESIA
}

\author{
Estimation of the Potential Economic Losses on Toddlers \\ Who Predicted Obesity as Adults in Indonesia \\ Brigitte Sarah Renyoet, Drajat Martianto, Dadang Iskandar \\ Departemen Gizi Masyarakat, Fakultas Ekologi Manusia, Institut Pertanian Bogor \\ (brigitte.sarah@yahoo.com)
}

\begin{abstract}
ABSTRAK
Makanan bergizi, seimbang, dan sesuai dengan kebutuhan tubuh masing-masing individu, harus diperhatikan. Terutama bagi balita yang membutuhkan asupan gizi untuk pertumbuhan dan perkembangan, akan tetapi makanan yang berlebih atau melebihi kebutuhan balita perlu untuk dihindari. Kondisi ini dapat mengakibatkan anak mengalami kelebihan berat badan dan obesitas. Penelitian bertujuan untuk melakukan estimasi besar potensi kerugian ekonomi akibat ketidakhadiran kerja pada balita obesitas ketika dewasa di Indonesia. Penelitian ini merupakan penelitian deskriptif dengan mengolah data dari berbagai instansi terkait serta merupakan data sekunder tahun 2013. Rumus estimasi kerugian ekonomi berasal dari penelitian Pitayatienanan et al., tahun 2014 dan faktor koreksi. Hasil penelitian menunjukan kerugian ekonomi akibat ketidakhadiran kerja karena obesitas pada balita secara nasional $0,003 \%-0,004 \%$ dari total PDB Indonesia. Ketidakhadiran kerja karena obesitas terlihat seperti bukan sebuah masalah, akan tetapi hasil estimasi ini menunjukkan dengan meningkatnya ketidakhadiran kerja dapat menghambat berkembangnya suatu negara karena berdampak pada ekonomi dan sumber daya manusianya. Kata kunci : Ekonomi, absensi, penyakit, produktivitas
\end{abstract}

ABSTRACT

The Nutritious, balanced food and suitable to the needs of each individual body, must be considered. Especially for toddlers who need nutrition for growth and development, however, excessive food or exceed the needs of toddlers need to be avoided. This condition can result in the child being overweight and obese. The study aims to estimate the amount of potential economic losses due to work absenteeism in toddlers who has experienced obesity into adulthood in indonesia. This research is descriptive by processing data from various institute and it is also a secondary data in 2013. the economic loss estimation formula stems from Pitayatienanan et al., 2014 research and a correction factor. The nationwide results showed economic losses due to absence from work because of obesity in toddler 0,003\% - 0,004\% of the total GDP of Indonesia. Absence from work due to the obesity looks like not a problem, but the results of these estimates indicate the increase in absenteeism can inhibit the growth of a country because the impact on the economy and it is human resources.

Keywords : Economic, absenteeism, disease, productivity 


\section{PENDAHULUAN}

Masalah gizi merupakan masalah kesehatan yang perlu diberikan perhatian lebih oleh pemerintah, karena masalah ini dapat memengaruhi segala lapisan masyarakat. Memenuhi kebutuhan gizi terutama diperlukan sejak masa janin sampai masa anak-anak berusia 5 tahun. Obesitas saat ini merupakan masalah yang mendunia dan organisasi kesehatan dunia atau World Health Organization (WHO) telah mendeklarasikan obesitas sebagai epidemik global. Menurut laporannya disebutkan pada tahun 2010 hampir 40 juta anak di bawah usia 5 tahun mengalami kegemukan.

Meningkatnya prevalensi kegemukan dan obesitas dari tahun ke tahun baik di negara maju maupun di negara berkembang. Menurut data survei National Health Examination and Nutrition Examination Survey tahun 2007-2008 yang menunjukkan meningkatnya kejadian obesitas berdasarkan indikator berat badan dan tinggi badan untuk anak usia 2-19 tahun diperkirakan sekitar $16,9 \%$ mengalami obesitas, sedangkan untuk anak usia 2-5 tahun diperkirakan sebanyak $10 \%$ pada tahun 2008 . $^{1}$

Sekitar 3,4 juta orang dewasa meninggal setiap tahun akibat dari kegemukan atau obesitas. Selain itu, 44\% karena diabetes, $23 \%$ penyakit jantung iskemik, serta antara $7 \%$ dan $41 \%$ karena kanker tertentu disebabkan oleh kegemukan dan obesitas. ${ }^{2}$ Penelitian Riset Kesehatan Dasar (Riskesdas) menunjukkan bahwa insiden balita gemuk pada tahun 2013 adalah $11,9 \%$. Terdapat beberapa provinsi yang memiliki masalah balita gemuk diatas prevalensi nasional, yaitu Lampung, Sumatera Selatan, Bengkulu, Papua, dan Riau. ${ }^{3}$

Obesitas tidak hanya memengaruhi kesehat- an pada anak, tetapi juga memengaruhi aktivitas akademik mereka, ${ }^{4}$ yang mungkin sebagian dijelaskan oleh masalah kesehatan dan ketidakhadiran. ${ }^{5}$ Beberapa faktor berperan dalam terjadinya obesitas yang sebagian besar merupakan hasil interaksi antara faktor lingkungan dengan faktor genetik, seperti gizi, aktivitas fisik, sosial ekonomi, pengetahuan, perilaku dan pola makan serta jumlah makanan yang dikonsumsi. ${ }^{6}$ Kurang aktivitas fisik karena anak-anak bermain video games dan menonton televisi dapat meningkatkan kejadian obesitas. ${ }^{7}$ Penyebab kegemukan saat usia anak-anak adalah kelainan metabolik seperti atherogene- sis, resistensi insulin, gangguan trombogenesis dan karsinogenesis. $^{8}$

Efek dari obesitas terus berlanjut sampai memengaruhi kesehatan dan pekerjaan mereka bila dibandingkan dengan orang yang memiliki berat badan normal. Kegemukan sering dihubungkan dengan penyakit degenaratif seperti hipertensi, diabetes tipe 2, dan penyakit kardiovaskuler. ${ }^{9}$ Penelitian kohort di Denmark menunjukkan ada hubungan linier yang positif antara kejadian penyakit jantung koroner pada sekitar 1.400 pria dan wanita dewasa yang memiliki riwayat Body Mass Index berlebih pada usia 7-13 tahun. ${ }^{10}$ Seki$\operatorname{tar} 50 \%$ remaja yang obesitas sudah mengalami obesitas sejak bayi, sedangkan penelitian lainnya di Jepang menunjukkan 1/3 dari anak yang obesitas tumbuh menjadi dewasa obesitas dan risiko obesitas ini diperkirakan sangat tinggi. ${ }^{11}$ Penelitian di Amerika memperlihatkan obesitas pada balita usia 1-2 tahun dengan orang tua normal menjadi dewasa obesitas sekitar $8 \%$, sedang obesitas pada usia 10-14 tahun dengan salah satu orang tua yang memiliki masalah obesitas sekitar 79\% akan menjadi dewasa obesitas. ${ }^{12}$

Beberapa negara pada orang gemuk menunjukkan mereka mengalami kesulitan dalam memperoleh pekerjaan, jika dibandingkan dengan seseorang dengan berat badan normal. Pekerja obesitas cenderung memiliki angka absensi yang tinggi dan produktivitas lebih rendah. Beberapa bukti menunjukan bahwa terjadinya peningkatan ketidakhadiran kerja pada pekerja yang mengalami obesitas dibandingkan dengan pekerja yang memiliki berat badan normal. ${ }^{13,14}$ Walaupun karyawan ratarata mengambil 7 hari libur sakit setiap tahun, ${ }^{15} \mathrm{di}$ London karyawan obesitas ditemukan secara signifikan mengambil rata-rata ekstra 4 hari sakit per tahun. ${ }^{16}$ Obesitas dikaitkan dengan peningkatan yang signifikan dalam ketidakhadiran kerja, hal ini ditunjukkan dengan meningkatnya ketidakhadiran di kalangan pekerja Amerika dan biaya kerugian negara adalah $\$ 8,65$ miliar per tahun akibat kehilangan produktivitas. ${ }^{17}$

Hasil ini menunjukan bahwa masalah obesitas menjadi beban ekonomi yang cukup besar pada negara sekitar6,5\%-12,6\% dari total biaya ketidakhadiran kerja di tempat kerja, sehingga negara dan pengusaha harus mencari cara yang lebih efektif untuk mengurangi biaya ini. Penelitian lainnya 
menunjukkan pekerja konstruksi yang overweight dan obesitas mengalami kecacatan kerja (work disability) dengan risiko cacat terendah pada Body MassIndeks (BMI) antara 25 dan $27,4 \mathrm{~kg} / \mathrm{m}^{2}$, sehingga kelebihan berat badan moderat tidak terkait dengan peningkatan risiko cacat pekerjaan karena osteoarthritis dan penyakit kardiovaskular. ${ }^{18}$ Hasil penelitian di Inggris menunjukkan dampak ekonomi dari kelebihan berat badan dan obesitassekitar $£ 5,1$ miliar, lebih tinggi dari biaya merokok $£ 3,3$ miliar dan biaya alkohol $£ 3,3$ miliar. ${ }^{19}$

Masalah obesitas di Indonesia saat ini diharapkan dapat segera diatasi oleh pemerintah. Bila melihat dari penelitian-penelitian sebelumnya, masih belum ada penelitian mengenai analisis ekonomi yang dapat mengungkapkan kerugian ekonomi akibat masalah gizi khususnya pada balita obesitas yang mengalami obesitas sampai dewasa di Indonesia. Berdasarkan pertimbangan tersebut, peneliti tertarik untuk melakukan penelitian ini. Tujuan penelitian adalah melakukan estimasi perhitungan kerugian ekonomi yang hilang akibat rendahnya produktivitas karena ketidakhadiran kerja.

\section{BAHAN DAN METODE}

Penelitian ini merupakan penelitian deskriptif. Penelitian ini dilakukan dengan mengolah data dari berbagai instansi terkait serta seluruh data yang diperoleh merupakan data sekunder. Kegiatan penelitian dilakukan di Bogor, Jawa Barat dan dilaksanakan mulai bulan Desember 2015 sampai Maret 2016. Jenis data yang dikumpulkan adalah data sekunder yang diperoleh dari berbagai instansi terkait di Indonesia. Data yang dikumpulkan berupa karakteristik balita di Indonesia (umur, jenis kelamin, data status gizi atau Z-score balita, jumlah balita $0-59$ bulan yang obesitas), ${ }^{3}$ karakteristik penduduk menurut provinsi (jumlah penduduk, jumlah kelahiran, jenis kelamin, dan kelompok umur), ${ }^{20,21}$ upah/gaji tenaga kerja (data upah/gaji/ pendapatan bersih pekerja menurut provinsi dan lapangan pekerjaan utama). ${ }^{22}$

Data yang diperoleh akan diolah menggunakan program Microsoft Excel. Tahapan rumus perhitungan yang digunakan untuk menghitung besarnya potensi ekonomi yang hilang akibat masalah obesitas pada balita dengan menggunakan rumus $^{23}$ dan menghitung jumlah dan prevalensi balita umur 3-5 tahun yang obesitas dengan menggunakan faktor koreksi ${ }^{24}$ karena tidak semua balita obesitas ketika dewasa nanti tetap mengalami masalah obesitas, sehingga kita menggunakan faktor koreksi untuk menghitung berapa peluang ketika dewasa tetap obesitas adalah sebagai berikut:

$$
\Sigma \mathrm{n}_{\mathrm{kor}}=\Sigma \mathrm{nx} \mathrm{f}_{\text {(cor) }}
$$

\section{Keterangan:}

$\Sigma \mathrm{n}_{\text {kor }}=$ Jumlah balita obesitas setelah dikoreksi

$\Sigma \mathrm{n}=$ Jumlah balita obesitas menurut umur dan jenis kelamin

$\mathrm{f}_{\text {(cor) }} \quad=$ Faktor Koreksi menurut umur dan jenis kelamin

Menghitung prevalensi balita yang saat ini obesitas dan nantinya ketika dewasa tetap obesitas dengan perhitungan berikut:

$$
\operatorname{Prev}_{\mathrm{kor}}=\Sigma \mathrm{n}_{\mathrm{kor}}: \Sigma \mathrm{np}
$$

\section{Keterangan:}

Prev $_{\text {kor }}=$ Prevalensi balita obesitas setelah koreksi $\Sigma \mathrm{n}_{\text {kor }}=$ Jumlah balita obesitas setelah dikoreksi $\Sigma$ np $=$ Jumlah balita penduduk sebelum dikorek si menurut jenis kelamin

Menghitung nilai ekonomi produktivitas ketidakhadiran kerja pada balita obesitas yang ketika dewasa mengalami masalah obesitas.Berikut rumus perhitungan yang digunakan. ${ }^{23}$ :

$$
\mathrm{CPLa}=\Sigma \mathrm{n}_{(\mathrm{l})(\mathrm{p})} \times \mathrm{AW} \times \operatorname{Nndio}_{(\mathrm{l})(\mathrm{p})} \times \mathrm{Pj}
$$

\section{Keterangan:}

$\mathrm{CPLa}=$ Nilai ekonomi produktivitas ketidakhadirankerja

$\mathrm{Sn}_{(1)}=$ Jumlah penduduk balita laki-laki obesitas yang telah dikoreksi

$\mathrm{Sn}_{(\mathrm{p})}=$ Jumlah penduduk balita perempuan obesitas yang telah dikoreksi

AW $=$ Upah/gaji harian (245 hari kerja)

$\Sigma$ ndio $_{(\mathrm{l})}=$ Jumlah hari dia rawat inap dan rawat jalan (laki-laki)

$\Sigma$ ndio $_{(\mathrm{p})}=$ Jumlah hari dia rawat inap dan rawat jalan (perempuan)

$\mathrm{Pj} \quad=$ Tingkat partisipasi kerja 
HASIL

Tabel 1 menunjukan besarnya prevalensi balita obesitas yang ada di Indonesia, prevalensi di atas menunjukkan sekitar 7,7\% balita di Indonesia tahun 2013 mengalami masalah obesitas. Beberapa provinsi memiliki prevalensi melebihi ratarata angka nasional, diantaranya adalah Provinsi Lampung, Banten, Sumatera Selatan, Bengkulu, Papua, Jambi, DKI Jakarta, dan Sumatera Utara. Provinsi yang memiliki prevalensi tertinggi adalah Provinsi Lampung 16,2\% dan Banten 14,5\%.

Tabel 2 menunjukan rata-rata besarnya po- tensi ekonomi yang hilang karena produktivitas kerja rendah akibat masalah obesitas pada balita di 33 provinsi yang ada di Indonesia adalah Rp 10 miliar pada laki-laki sedangkan pada perempuan sebesar Rp 11 miliar. Sehingga dapat dikatakan rata-rata potensi ekonomi yang hilang di 33 provinsi yang ada di Indonesia yaitu Rp 10 miliar - Rp 11 miliar, jika dilihat dalam persentase terhadap Produk Domestik Regional Bruto (PDRB) maka besarnya potensi ekonomi yang hilang akibat ketidakhadiran kerja karena masalah obesitas, yaitu sekitar $0,006 \%$ - 0,008\% dari rata-rata PDRB

Tabel 1. Prevalensi Balita Obesitasdi Indonesia Tahun 2013

\begin{tabular}{|c|c|c|}
\hline Provinsi & Prevalensi Obesitas (\%)* & Jumlah Balita Obesitas \\
\hline Aceh & 6,2 & 70.241 \\
\hline Sumatera Utara & 9,3 & 41.112 \\
\hline Sumatera Barat & 6,2 & 15.561 \\
\hline Riau & 8,9 & 148.486 \\
\hline Jambi & 10,1 & 23.090 \\
\hline Sumatera Selatan & 11,9 & 29.606 \\
\hline Bengkulu & 11,6 & 116.907 \\
\hline Lampung & 16,2 & 12.988 \\
\hline Kep. Bangka Belitung & 7,1 & 41.545 \\
\hline Kepulauan Riau & 6,1 & 530.875 \\
\hline DKI Jakarta & 9,3 & 348.276 \\
\hline Jawa Barat & 7,0 & 367.152 \\
\hline Jawa Tengah & 7,8 & 61.232 \\
\hline D.I. Yogyakarta & 5,2 & 53.510 \\
\hline Jawa Timur & 7,2 & 28.011 \\
\hline Banten & 14,5 & 49.122 \\
\hline Bali & 8,1 & 27.290 \\
\hline Nusa Tenggara Barat & 5,0 & 101.583 \\
\hline Nusa Tenggara Timur & 4,9 & 24.831 \\
\hline Kalimantan Barat & 8,2 & 16.696 \\
\hline Kalimantan Tengah & 7,8 & 57.645 \\
\hline Kalimantan Selatan & 5,9 & 73.268 \\
\hline Kalimantan Timur & 7,4 & 42.147 \\
\hline Sulawesi Utara & 6,6 & 11.417 \\
\hline Sulawesi Tengah & 4,3 & 85.102 \\
\hline Sulawesi Selatan & 4,4 & 16.582 \\
\hline Sulawesi Tenggara & 7,3 & 103.794 \\
\hline Gorontalo & 4,2 & 36.882 \\
\hline Sulawesi Barat & 7,2 & 37.300 \\
\hline Maluku & 7,7 & 25.073 \\
\hline Maluku Utara & 4,9 & 101.913 \\
\hline Papua Barat & 4,2 & 65.411 \\
\hline Papua & 10,3 & 197.678 \\
\hline Indonesia & 7,7 & 2.976 .176 \\
\hline
\end{tabular}

*Hasil olah data mikro (Riskesdas 2013) oleh peneliti

Sumber: BPS 2013, Badan Penelitian dan Pengembangan Kesehatan 2013 
Tabel 2. Estimasi Kehilangan Potensi Ekonomi karena Obesitas pada Balita

\begin{tabular}{|c|c|c|c|c|}
\hline \multirow{2}{*}{ Provinsi } & \multirow{2}{*}{$\begin{array}{c}2 \% \\
\text { (rupiah) }\end{array}$} & \multirow{2}{*}{$\begin{array}{c}9 \% \\
\text { (rupiah) }\end{array}$} & \multicolumn{2}{|c|}{$\%$ PDRB } \\
\hline & & & $2 \%$ & $9 \%$ \\
\hline Aceh & 8.461 .095 .651 & 13.681 .022 .454 & 0,009 & 0,015 \\
\hline Sumatera Utara & 21.862 .469 .663 & 31.310 .366 .381 & 0,005 & 0,008 \\
\hline Sumatera Barat & 14.532 .381 .486 & 14.579 .628 .668 & 0,011 & 0,011 \\
\hline Riau & 6.507 .934 .480 & 6.984 .203 .529 & 0,002 & 0,002 \\
\hline Jambi & 2.401 .970 .240 & 3.168 .939 .563 & 0,003 & 0,004 \\
\hline Sumatera Selatan & 10.727 .996 .193 & 8.044.233.098 & 0,006 & 0,004 \\
\hline Bengkulu & 1.541 .475 .020 & 1.546 .465 .243 & 0,006 & 0,006 \\
\hline Lampung & 6.044 .839 .682 & 6.751 .270 .655 & 0,004 & 0,004 \\
\hline Kep. Bangka Belitung & 931.367 .468 & 1.126 .820 .040 & 0,002 & 0,003 \\
\hline Kepulauan Riau & 3.704 .897 .750 & 3.471 .607 .230 & 0,004 & 0,004 \\
\hline DKI Jakarta & 25.053 .547 .788 & 25.474 .578 .831 & 0,002 & 0,002 \\
\hline Jawa Barat & 71.073 .603 .703 & 78.806 .266 .871 & 0,007 & 0,008 \\
\hline Jawa Tengah & 32.027 .420 .773 & 34.441 .518 .451 & 0,006 & 0,006 \\
\hline D.I. Yogyakarta & 2.249 .782 .566 & 1.633 .895 .928 & 0,004 & 0,003 \\
\hline Jawa Timur & 59.347 .186 .315 & 49.059 .980 .243 & 0,005 & 0,004 \\
\hline Banten & 17.173 .887 .858 & 11.904 .549 .070 & 0,007 & 0,005 \\
\hline Bali & 3.514 .028 .021 & 3.246 .989 .613 & 0,004 & 0,003 \\
\hline Nusa Tenggara Barat & 2.861 .603 .464 & 5.301 .378 .279 & 0,005 & 0,009 \\
\hline Nusa Tenggara Timur & 4.799 .582 .311 & 6.273 .173 .131 & 0,012 & 0,016 \\
\hline Kalimantan Barat & 3.601 .931 .111 & 2.845 .704 .128 & 0,004 & 0,003 \\
\hline Kalimantan Tengah & 1.805 .818 .009 & 2.611.121.823 & 0,003 & 0,004 \\
\hline Kalimantan Selatan & 6.302 .009 .449 & 7.807.563.395 & 0,008 & 0,009 \\
\hline Kalimantan Timur & 7.605 .105 .085 & 7.768 .689 .833 & 0,003 & 0,003 \\
\hline Sulawesi Utara & 2.120 .276 .664 & 6.095 .950 .535 & 0,004 & 0,011 \\
\hline Sulawesi Tengah & 3.913 .778 .943 & 3.795 .267 .216 & 0,007 & 0,007 \\
\hline Sulawesi Selatan & 8.395 .858 .845 & 18.100 .868 .788 & 0,005 & 0,010 \\
\hline Sulawesi Tenggara & 1.799 .408 .743 & 2.332 .269 .407 & 0,004 & 0,006 \\
\hline Gorontalo & 522.768 .375 & 1.112 .965 .567 & 0,004 & 0,009 \\
\hline Sulawesi Barat & 1.218 .327 .533 & 451.222 .131 & 0,008 & 0,003 \\
\hline Maluku & 2.391 .853 .938 & 2.300 .732 .497 & 0,018 & 0,017 \\
\hline Maluku Utara & 1.334 .580 .574 & 2.660 .880 .829 & 0,017 & 0,034 \\
\hline Papua Barat & 720.056 .098 & 1.483 .652 .712 & 0,003 & 0,007 \\
\hline Papua & 3.653 .549 .904 & 5.841 .505 .864 & 0,004 & 0,006 \\
\hline
\end{tabular}

Keterangan: PDRB atas dasar harga berlaku tanpa migas

Sumber: Hasil olah data dan perhitungan peneliti

provinsi-provinsi yang ada di Indonesia.

Potensi ekonomi yang hilang akibat obesitas pada balita secara nasional, ketika dewasa pada balita laki-laki yaitu Rp 260.122 miliar dan pada perempuan sebesar Rp 371.115 miliar. Jika melihat nilai-nilai ini dalam persentase terhadap Produk Domestik Bruto (PDB) Indonesia maka besarnya potensi kerugian ekonomi akibat penurunan produktivitas karena obesitas secara nasional yaitu $0,003 \%$ pada laki-laki dan perempuan mencapai $0,004 \%$ dari total PDB Indonesia. Secara nasional, dapat dikatakan besar potensi ekonomi yang hilang akibat ketidakhadiran kerja karena masalah obesitas pada balita adalah Rp 260 - Rp 371 miliar atau 0,003\% - 0,004\% dari total PDB Indonesia.

Provinsi dengan nilai kerugian ekonomi tertinggi yang hilang adalah Jawa Barat sekitar Rp 71 miliar pada laki-laki dan Rp 79 miliar pada perempuan. Persentase kehilangan potensi ekonomi akibat penurunan produktivitas terhadap PDRB provinsinya adalah $0,07 \%$ pada laki-laki dan $0,08 \%$, sedangkan provinsi dengan potensi ekonomi yang hilang terendah adalah Gorontalo dengan nilai kehilangan ekonomi sekitar $\mathrm{Rp}$ 
0,52 miliar pada laki-laki dan Sulawesi Barat kehilangan potensi ekonomi akibat ketidakhadiran kerja pada perempuan sebesar Rp 0,45 miliar atau persentase kehilangan terhadap PDRB untuk Gorontalo dan Sulawesi Barat adalah 0,004\% dan $0,003 \%$ terhadap PDRB provinsi masing-masing.

\section{PEMBAHASAN}

Masalah balita gemuk saat ini perlu mendapatkan perhatian dari pemerintah, sehingga nantinya mereka menjadi generasi yang lebih produktif dan dapat membangun negara ini. Hal ini bisa terwujud jika kesehatan bukan lagi menjadi masalah, terutama masalah kesehatan yang diakibatkan oleh kelebihan gizi. Balita yang gemuk bukan hanya berarti mereka sehat, tetapi bisa menjadi masalah kesehatan lainnya seperti beberapa penyakit degenaratif, sehingga asupan makanan dan berat badan mereka harus diperhatikan. Menurut World Health Organization (WHO) obesitas sudah dialami oleh anak-anak di bawah usia 5 tahun, hal ini dilihat dari jumlahnya pada tahun 2012 yang diperkirakan sekitar 44 juta atau $6,7 \%$ dari anakanak di bawah usia 5 tahun yang kelebihan berat badan atau obesitas di seluruh dunia. ${ }^{25}$ Berdasarkan angka ini, prevalensi global kelebihan berat badan dan obesitas pada anak telah berkembang dari sekitar 5\% tahun 1990 menjadi 7\% pada tahun 2012.

Menurut Kementerian Kesehatan anak yang mengalami obesitas serta kurang aktivitas fisik, ruang gerak yang terbatas maka anak dapat mengalami gangguan pernapasan dan komplikasi ortopedik (tulang). ${ }^{26}$ Konsumsi makanan manis dan tinggi lemak, pola hidup yang kurang sehat, maka risiko balita gemuk akan menimbulkan peluang terjadinya berbagai penyakit, antara lain gangguan penyakit hati; gangguan saluran pernapasan ketika anak tidur, adanya gejala anak sering mengompol sampai mengorok ketika tidur; serta usia yang lebih pendek daripada generasi orang tuanya. Melihat berbagai masalah kesehatan yang dapat ditimbulkan oleh obesitas maka dianggap sebagai salah satu faktor yang dapat meningkatkan prevalensi masalah penyakit tidak menular seperti intoleransi glukosa, hipertensi, dan penyakit jantung koroner aterosklerotik pada pasien yang obesitas. ${ }^{27}$

Obesitas adalah suatu kondisi abnormal atau akumulasi kelebihan lemak di jaringan adi- posa, yang dapat memengaruhi kesehatan tubuh dan meningkatkan masalah kesehatan. Meskipun mekanisme terjadinya obesitas tidak sepenuhnya dipahami, tetapi hal itu menegaskan bahwa obesitas terjadi ketika asupan energi melebihi pengeluaran energi. ${ }^{28}$ Melihat dari keadaan ini maka dapat dikatakan bahwa tentunya orang yang obesitas ini karena mengkonsumsi makanan yang berlebih terutama makanan tinggi lemak dan gula, juga memiliki aktivitas fisik yang rendah. Jika terus dibiarkan seperti ini, maka dapat menyebabkan gangguan kesehatan dan mengganggu aktifitas sehari-hari salah satunya adalah mengganggu pekerjaan. Rendahnya produktivitas ini berdampak pada kondisi ekonomi, selain berdampak pada ekonomi individu juga berdampak pada persentase terhadap PDRB dan PDB karena masalah obesitas, sehingga sangat perlu untuk diperhatikan oleh pemerintah pusat maupun daerah.

Hasil estimasi besar kerugian ekonomi karena penurunan produktivitas kerja dengan menggunakan rumus perhitungan dari penelitian ${ }^{23}$ dan faktor koreksi. ${ }^{24}$ Prevalensi yang telah diperoleh merupakan probabilitas balita obesitas yang nantinya ketika dewasa akan tetap mengalami masalah obesitas, selanjutnya menghitung nilai ekonomi produktivitas ketidakhadiran kerja yang nantinya akan digunakan untuk menghitung besar potensi kerugian ekonomi akibat ketidakhadiran kerja karena masalah obesitas pada balita di 33 provinsi yang ada di Indonesia.

Hasil penelitian negara lain seperti di Inggris dengan kehilangan biaya akibat ketidakhadiran kerja karena obesitas sekitar \$5 juta yang hilang akibat penurunan produktivitas kerja. ${ }^{29} \mathrm{Di}$ Amerika para pekerja full-time yang kelebihan berat badan atau obesitas, serta memiliki kondisi kesehatan kronis lainnya diperkiraan biaya kehilangan produktivitas lebih dari \$153 miliar setiap tahunnya. Biaya produktivitas yang hilang dalam analisis ini akan meningkat jika itu termasuk presenteeism, ketika karyawan yang datang untuk bekerja, tetapi kurang produktif dalam pekerjaan mereka karena kondisi kesehatannya buruk. ${ }^{30}$ Jawa Barat kehilangan potensi ekonomi yang tinggi baik pada laki-laki dan perempuan, sebaliknya pada laki-laki di Provinsi Gorontalo dan perempuan di Provinsi Sulawesi Barat yang rendah kehilangan potensi ekonominya karena beberapa fak- 
tor yang memengaruhi seperti prevalensi masalah obesitas, rata-rata hari tidak bekerja akibat masalah obesitas, jumlah penduduk balita, serta gaji/ upah setiap provinsi oleh karena itu hal ini berlaku untuk provinsi lainnya yang memiliki jumlah gaji/ upah yang bervariasi atau berbeda sesuai dengan keadaan ekonomi dan kebijakan dari masingmasing wilayah, seperti semakin tingginya upah/ gaji maka nilai kehilangan potensi ekonomi akibat ketidakhadiran kerja menjadi tinggi. Pada Provinsi Gorontalo yang lebih rendah kerugian ekonominya yaitu pada laki-laki karena perbedaan prevalensi masalah obesitas dan jumlah penduduk balita laki-laki dan perempuannya, sedangkan pada Provinsi Sulawesi Barat yang kerugian ekonominya lebih rendah pada perempuan karena prevalensi masalah obesitas, jumlah penduduk balita, dan upah/gaji laki-laki dan perempuan.

\section{KESIMPULAN DAN SARAN}

Secara nasional, besar potensi kerugian ekonomiakibat ketidakhadiran kerja karena obesitas pada balita secara nasional sekitar Rp 260 miliar - Rp 371 miliar atau 0,003\% - 0,004\% dari total PDB Indonesia. Provinsi dengan nilai kerugian ekonomi tertinggi yang hilang adalah Jawa Barat sekitar Rp 71 miliar pada laki-laki dan $\mathrm{Rp}$ 79 miliar pada perempuan. Persentase kehilangan potensi ekonomi akibat penurunan produktivitas terhadap PDRB provinsinya adalah $0,07 \%$ pada laki-laki dan $0,08 \%$, sedangkan provinsi dengan potensi ekonomi yang hilang terendah adalah Gorontalo dengan nilai kehilangan ekonomi sekitar Rp 0,52 miliar pada laki-laki dan Sulawesi Barat kehilangan potensi ekonomi akibat ketidakhadiran kerja pada perempuan sebesar Rp 0,45 miliar atau persentase kehilangan terhadap PDRB untuk Gorontalo dan Sulawesi Barat adalah $0,004 \%$ dan $0,003 \%$ terhadap PDRB provinsi masing-masing. Penelitian ini membahas mengenai kerugian ekonomi akibat ketidakhadiran kerja karena obesitas, akan lebih baik jika penelitian ini bisa berlanjut dilakukan untuk mencari nilai kerugian ekonomi akibat presenteeism yaitu ketika karyawan obesitas datang untuk bekerja, tetapi kurang produktif dalam melakukan pekerjaannya yang dikarenakan kondisi kesehatan yang buruk.

\section{UCAPAN TERIMAKASIH}

Penulis menyampaikan terimakasih kepada Susan E. Horton, Ph.D yang telah banyak membantu baik dalam pemberian saran maupun referensi bagi penulis.

\section{DAFTAR PUSTAKA}

1. Central for Disease Control. Overweight and Obesity [Internet]. [diunduh 2016 Mei 26]. Tersedia pada: http://www.cdc.gov; 2009.

2. World Health Organization.Overweight and Obesity [Internet]. [diunduh 2015 Oktober 10]. Tersedia pada: http://www.who.int/media centre/factsheets/fs311/en/; 2014a.

3. Badan Penelitian dan Pengembangan Kesehatan. Laporan Hasil Riset Kesehatan Dasar Indonesia Tahun 2013. Jakarta : Kementerian Kesehatan Republik Indonesia; 2013

4. Booth JN, Tomporowski PD, Boyle JM, Ness AR, Joinson C, Leary SD, Reilly JJ. Obesity Impairs Academic Attainment in Adolescence: Finding from ALSPAC, a UK cohort. Int J Obes (Lond). 2014;38(10):1335-42.Doi: 10.1038/ijo.2014.40.

5. Wijga AH, Scholtens S, Bemelmans WJ, de Jongste JC, Kerkhof M, Schipper M, Sanders EA, Gerritsen J, Brunekreef B, Smit HA. Comorbidities of Obesity in Sschool Children: a Cross-sectional Study in the PIAMA Birth Cohort. BMC Public Health. 2010;10:184. Doi: 10.1186/1471-2458-10-184.

6. Octari C ,Liputo NI, Edison. Hubungan Status Ekonomi dan Gaya Hidup dengan Kejadian Obesitas pada Siswa SDN 08 Alang Lawas Padang. Jurnal Kesehatan Andalas.2014;3(2).

7. Adiwinanto W. Pengaruh Intervensi Olahraga di Sekolah terhadap Indeks Massa Tubuh dan Tingkat Kebugaran Kardiorespirasi pada Remaja Obesitas [Skripsi]. Semarang: Universitas Diponegoro; 2008.

8. Hanley AJ, Harris SB, Gittelsohn J, Wolever TM, Saksvig B, Zinman B. Overweight among Children and Adolescent in a Native Canadian Community: Prevalence and Associated Factors. American Journal of Clinical Nutrition. 2000;71:693-700.

9. Moschonis G, Grammatikaki E, Manios Y. Perinatal Predictors of Overweight an Infan- 
cy and Preschool Childhood: the GENESIS study. International Journal of Obesity. 2007; 32:39-47.

10. Baker JL, Olsen LW, Sørensen TI. Childhood Body-Mass Index and the Risk of Coronary Heart Disease in Adulthood. N Engl J Med. 2007;357(23):2329 - 37.

11. Taitz LS. Obesity, Dalam Textbook Of Pediatric Nutrition, IIIrd ed, McLaren DS, Burman D, Belton NR, Williams AF, (Editors). 485 509. London: Churchill Livingstone; 1991.

12. Hidayati SN, Irawan R, Hidayat B. Obesitas Pada Anak [Online]. [diunduh 2016 Desember 5]. Tersedia pada: www.pediatrik.com/buletin/06224113652-048qwc.pdf; 2006.

13. Neovius K, Johansson K, Kark M, Neovius M. Obesity Status and Sick Leave: a Systematic Review. Journal NCBI. 2008;10(1):17 - 27.

14. van Duijvenbode DC, Hoozemans MJM, van Poppel, Proper KI. 2009. The Relationship between Overweight and Obesity, and Sick Leave: a Systematic Review. Journal NCBI. 2009;33(8):807-816.

15. Sainsbury Centre for Mental Health. Mental Health at Work: Developing the Business Case [Internet]. SCMH, London. [diunduh 2016 Maret 20]. Tersedia pada: http://bit. ly/1vTkAld; 2007.

16. Harvey SB, Glozier N, Carlton O, Mykletun A, Henderson M, Hotopf M, Holland-Elliott K. Occup Med (Lond). 2010;60(5):362-8. Doi: $10.1093 /$ occmed/kqq031.

17. Claessen H, Amdt V, Drath C, Brenner H. Overweight, Obesity and Risk of Work Disability: a Cohort Study of Construction Workers in Germany. J Occup environ med. 2014;66(6): 402-409. Doi: 10.1136/oem.2008.042440.

18. Badan Pusat Statistik. Laporan Bulanan Data Sosial Ekonomi. Edisi 55 Desember 2014. Jakarta : Badan Pusat Statistik Republik Indonesia; 2014.

19. Scarborough P, Bhatnagar P, Wickramasinghe KK, Allender S, Foster C, Rayner M. The Economic Burden of Ill Health Due to Diet, Physical Inactivity, Smoking, Alcohol and Obesity in the UK: an update to $2006-07$ NHS Costs. Journal of Public Health. 2011; 1-9. Doi:10.1093/pubmed/fdr033.

20. Kementerian Kesehatan Republik Indonesia.
"InfoDATIN" Situasi Kesehatan Anak balita di Indonesia.ISSN 2442-7659. Jakarta : Pusat Data dan Informasi Kementerian Kesehatan RI; 2015.

21. Badan Pusat Statistik. Laporan Bulanan Data Sosial Ekonomi. Edisi 55 Desember 2014. Jakarta : Badan Pusat Statistik Republik Indonesia; 2014.

22. Badan Pusat Statistik. Keadaan Pekerja di Indonesia November 2013. Jakarta : Badan Pusat Statistik Republik Indonesia; 2013.

23. Pitayatienanan P, Butchon R, Yothasamut J, Aekplakorn W, Teerawattananon Y, Suksomboon N, Thavorncharoensap M. Economic Costs of Obesity in Thailand: a Retrospective Cost-of Illness Study. BMC Health Services Research. 2014;14:146.

24. Guo SS, Wu W, Chumlea WC, Roche AF. Predicting Overweight and Obesity in Adulthood from Body Mass Index Values in Childhood and Adolescence. Am J Clin Nutr. 2002;76: 653-658.

25. World Health Organization. World Health Statistics 2014 Geneva: WHO [Internet]. [diunduh 2015 Oktober 10]. Tersedia pada: http:// www.who.int/media centre/factsheets/fs311/ en/; 2014b.

26. Kementerian Kesehatan Republik Indonesia. "InfoDATIN" Situasi Kesehatan Anak balita di Indonesia. ISSN 2442-7659. Jakarta : Pusat Data dan Informasi Kementerian Kesehatan RI [Internet]. [diunduh 2015 Oktober 11]. Tersedia pada: http://www.depkes.go.id; 2015.

27. American Heart Association. Heart International Cardiovascular Disease Statistic [Internet]. [diunduh 2015 Oktober 13]. Tersedia pada: http://www.american heart.org/; 2011.

28. Rathnayake KM, Satchithananthan A, Mahamithawa S, Jayawardena R. Early Life Predictors of Preschool Overweight and Obesity: a Case-Control Study in Sri Lanka. BMC Public Health. 2013;22(33):994. Doi: 10.1186/14712458-13-994.

29. Dobbs R, Sawers C, Thompson F, Manyika J, Woetzel J, Child P, McKenna S,Spatharou A. Overcoming Obesity: An Initial Economic Analysis. The McKinsey Global Institute (MGI); 2014.

30. Witters D, Agrawal S. 2011. Unhealthy U.S. 
Workers' Absenteeism Costs \$153 Billion [Internet]. Gallup Well-being. [diunduh 2015 Oktober 10]. Tersedia pada: http://www.gal- lup.com/poll/150026/unhealthy-workers-absenteeism-costs153billion.aspx. 